\title{
Wildlife disturbance and winter recreational activities in Alpine protected areas: recommendations for successful management
}

\author{
Dominik Cremer-Schulte, Maik Rehnus, Antoine Duparc, Clémence Perrin-Malterre \& Letizia Arneodo
}

Keywords: outdoor recreation, protected areas, wildlife disturbance, visitor management, public awareness, evaluation, winter

\section{Abstract}

Winter recreational activities such as ski touring, free riding snow sports and snowshoeing have become ever more popular in the Alps in recent decades, with increases in both the number of activities and user demand. Increased human presence in Alpine natural zones causes disturbance to wildlife and its behaviour, leading to psychological stress responses and increased nutritional and energy requirements. Alpine protected areas have set up management strategies and tools in order to protect wildlife and its habitats while preserving high levels of outdoor recreation value. In the present article, we give an overview of best practices of visitor management and information campaigns in Alpine protected areas. Based on existing knowledge and experience gathered during an international workshop of the Alpine network of protected areas, we highlight five components that are crucial for the successful management of winter recreational activities and provide recommendations for management practice.

\section{Introduction}

Winter recreational activities such as ski touring, free-riding snow sports and snowshoeing have become ever more popular in the Alps during recent decades, with increases both in the number of activities and user demand (Manning \& Anderson 2012; Immoos \& Hunziker 2015), which have expanded into previously unattained and sensitive zones (Margraf et al. 1999). These activities thus increase pressure on biodiversity and cause significant behavioural responses in the Alpine fauna (Ingold 2005; Sato et al. 2013; Larson et al. 2016). Disturbance notably increases the nutritional and energy requirements of wildlife and can lead to increased damage to vegetation, such as bark-stripping (Reimoser 2012). Research has shown impacts of winter recreational activities on many taxa, especially birds and mammals (Sato et al. 2013; Larson et al. 2016). The vast majority of winter recreationists lack awareness of the significant impacts disturbance might cause and consequently underestimate the impact of their behaviour (Perrin-Malterre et al. 2016). Often, motivations such as pleasure, freedom and performance are in the foreground (Zeidnitz et al. 2007). Conflicts between conservationists and recreationists are therefore very common, especially where protected areas (PAs) or endangered species are present (Immoos \& Hunziker 2015). These conflicts increase the need for management strategies that are based on dialogue and an appropriate mix of guidance and information tools.

Over the last 20 years, Alpine PAs, wildlife managers, environmental NGOs and Alpine clubs have developed various visitor management and information campaigns to reduce disturbance impacts on wildlife. In March 2016, the international workshop Wildlife and winter sport activities gathered together a wide range of stakeholders from the Alps in the Massif des Bauges
Regional Nature Park (French Alps). We summarize the knowledge on disturbance shared at this workshop and give an overview of best practices of visitor management and information campaigns across the Alps. Following the presentation of five major components that are essential for the successful management of winter recreational activities, we provide recommendations for management practice.

\section{Wildlife disturbance and winter recreation- al activities}

Alpine wildlife has different strategies to cope with usual environmental conditions in winter, such as harsh weather conditions and lower resource availability. For instance, mountain hare (Lepus timidus) reduce their metabolic rate instead of depleting fat reserves (Rehnus et al. 2010), and rock ptarmigan (Lagopus muta) reduce the metabolic cost of locomotion (Less et al. 2010). But wild animals must also cope with unpredictable levels of human disturbance in winter, leading to behavioural changes and possible physiological stress responses (Table 1). Chronically elevated stress levels affect metabolism, immune response, reproduction and survival (Boonstra et al. 1998; Sapolsky et al. 2000; Sheriff et al. 2009; Clinchy et al. 2011). In winter, both physiological and behavioural responses are often combined with extra energetic costs (Baltic et al. 2005; Rehnus et al. 2014; Arlettaz et al. 2015), and trade-offs between response to stress and other functions such as physiological balance and reproduction.

Current research also tries to understand the attitudes and behaviour of participants in outdoor activities (e.g. Sterl et al. 2010). However, whereas there is substantial knowledge on the impacts of recreational activities on wildlife, there is a lack of knowledge regarding outdoor participants' behaviour (Sato et al. 2013), especially in winter. Motivations for spend- 
Table 1 - Examples of wildlife responses to human disturbance in the Alps in winter. Source: Authors' compilation.

\begin{tabular}{|c|c|c|c|}
\hline \multicolumn{2}{|c|}{ Species } & \multirow[t]{2}{*}{ Response to disturbance } & \multirow[t]{2}{*}{ Reference } \\
\hline Scientific name & Common name & & \\
\hline \multicolumn{4}{|l|}{ Aves } \\
\hline \multicolumn{4}{|l|}{ Galliformes } \\
\hline Tetrao urogallus & Capercaillie & Increased stress hormone levels & Thiel et al. 2011 \\
\hline \multirow[t]{4}{*}{ Tetrao tetrix } & \multirow[t]{4}{*}{ Black grouse } & Higher concentrations of corticosterone metabolites & Formenti et al. 2015 \\
\hline & & Negative effect on the local abundance in ski-lift areas & Patthey et al. 2008 \\
\hline & & Costly allostatic behavioural and energetic adjustments & Arlettaz et al. 2015 \\
\hline & & Behavioural changes (increased flushing distance) & Baines \& Richardson 2007 \\
\hline \multicolumn{4}{|l|}{ Mammalia } \\
\hline \multicolumn{4}{|l|}{ Lagomorpha } \\
\hline Lepus timidus & Mountain hare & $\begin{array}{l}\text { Increased stress hormone excretion, behavioural changes and energy } \\
\text { demand }\end{array}$ & Rehnus et al. 2014 \\
\hline \multicolumn{4}{|l|}{ Carnivora } \\
\hline Canis lupus & Wolf & Faecal glucocorticoid metabolites were higher in areas used by humans & Creel et al. 2002 \\
\hline Martes martes & Pine marten & Faecal glucocorticoid metabolites were higher in areas used by humans & Barja et al. 2007 \\
\hline \multicolumn{4}{|l|}{ Artiodactyla } \\
\hline \multirow[t]{2}{*}{ Cervus elaphus } & \multirow[t]{2}{*}{ Elk } & $\begin{array}{l}\text { Faecal glucocorticoid metabolites paralleled variation in the number of } \\
\text { snowmobiles }\end{array}$ & Creel et al. 2002 \\
\hline & & Increased heart rates and behaviour changes & Herbold et al. 1994 \\
\hline $\begin{array}{l}\text { Rupicapra rupi- } \\
\text { capra }\end{array}$ & Chamoix & $\begin{array}{l}\text { Changes in behavior to ensure safety in response to speed of sport ac- } \\
\text { tivity, hiker's position in relation to animal, hiker's noise level, colour of } \\
\text { hiker's clothes, occurrence of aircraft (e.g. glider, helicopter, aeroplane) }\end{array}$ & Ingold 2005 \\
\hline $\begin{array}{l}\text { Capreo luscapreo- } \\
\text { lus }\end{array}$ & Roedeer & Increased heart rates and behaviour changes & Herbold et al. 1994 \\
\hline
\end{tabular}

ing time outdoors vary across different user groups (Zeidnitz et al. 2007), ranging from nature observation and pleasure to performance-seeking (Perrin-Malterre et al. 2016). Current research is particularly interested in the variety of human responses to wildlife while outdoors. For instance, encountering wild animals can trigger positive emotions (Jacobs et al. 2012; PerrinMalterre et al. 2016).

Research also analyses recreationists' perceptions of the impacts of their presence on wildlife. Studies show that the majority of recreationists do not perceive any effect (Perrin-Malterre et al. 2016; Le Corre et al. 2013; Hardiman \& Burgin 2010; Sterl et al. 2008, 2010; Taylor \& Knight 2003). As a result, certain user groups do not always accept the management and guidance measures implemented in sensitive areas, especially if the activity is pleasure- or performanceoriented. Better knowledge of outdoor recreation impacts on wildlife could improve the acceptance of these measures among recreationists (Cornelisse \& Duan 2013; Manning \& Anderson 2012). Some wildlife managers, NGOs and Alpine clubs have therefore set up information campaigns in combination with on-site visitor management measures.

\section{Management of winter recreational activi- ties to diminish wildlife disturbance: needs and recommendations}

Governments, environmental NGOs and PA managers pursue the same overall goal for managing outdoor recreation in the Alps in winter: to protect native wildlife and its habitats and promote respectful human behaviour towards wildlife while preserving high lev- els of outdoor recreational benefits (Immoos \& Hunziker 2015; Manning \& Anderson 2012). Experts have put forward numerous guiding principles for outdoor recreation that are ecologically compatible with nature and wildlife (Table 2; Margraf et al. 1999). Since disturbance in winter is particularly harmful to wildlife populations, the international exchange of experts at the workshop highlighted five essential components for the successful management of winter recreational activities (Figure 1). These elements should be covered when elaborating management strategies for PAs and their regions.

Within this framework, two important dimensions to be taken into account are the spatial and temporal scales of management action. Wildlife habitats, the mobility of fauna, recreational activities and management responsibilities all vary significantly in spatial extent. To be both efficient and effective, spatial scales of monitoring, visitor management and information need to be integrated at the appropriate scale for the regional context, e. g. a mountain massif, valley, tourist destination or PA.

\section{Survey and monitoring}

Adequate knowledge of fauna, recreational activities and their interaction is crucial to evaluate disturbance levels and to reconcile recreation and wildlife needs. In order to evaluate whether disturbance is critical in a given area, managers must analyse interactions between wildlife and outdoor recreationists. This requires gathering information, monitoring and evaluation in both the spatial and temporal dimensions of disturbance.

Across the Alps, researchers and wildlife managers have undertaken continuous monitoring. Thus, knowl- 


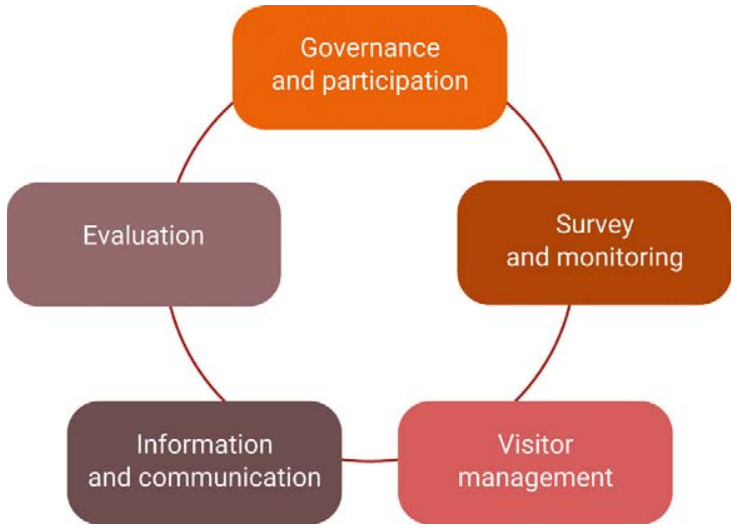

Figure 1 - Essential components for successful management of winter recreational activities.

edge of habitats and behaviour in winter of emblematic species such as black grouse, chamois and capra ibex is generally good in PAs. Other species are expected to benefit from the habitat protection for emblematic species (the so-called umbrella species effect, Launer \& Murphy 1994). In nature reserves of the Northern French Alps, for instance, wildlife managers have designed an easy-to-use, transferable protocol to assess black grouse wintering habitats. However, since monitoring and field surveys are resource-intensive, expert judgements often remain the sole base for managers' decision-making (ALPARC 2016). Similarly, little verified and consistent information is available on winter recreational activities, i. e. their extent or frequency, and users' motivations and behaviour (Sato et al. 2013). This is seen by managers as an important obstacle to improving management and wildlife protection.

\section{Recommendations}

- Species distribution does not coincide spatially with administrative or PA boundaries, and management strategies and plans for recreational activities vary between countries and regions. Researchers and wildlife managers should therefore engage in harmonizing information, management and protection methods, and actively share knowledge and experience acquired in specific (protected) areas of the Alps.

- In order to improve the management of conflicts between recreational activities and wildlife in winter, a suitable survey protocol for monitoring wildlife disturbance by recreationists is needed. Such survey protocols should account for differences in winter recreational activities, in national contexts and in scales of disturbance.

- Politics and decision-makers should support innovative research projects that take an integrated approach to monitoring outdoor recreation and wildlife disturbance.

\section{Visitor management}

Visitor management strategies and plans set up by Alpine PA managers aim at protecting wildlife and hab-
Table 2 - Guiding principles for management of outdoor recreation (Margraf et al. 1999).

1. Particularly valuable natural zones have to be given increased protection against damaging outdoor recreational activities.

2. Where natural zones are used by humans, the utilization has to be compatible with local wildlife and its habitats.

3. Environmental awareness-raising and education are important in order to promote such compatible use and to counteract human alienation from nature, wildlife and its habitats.

itats while offering high-quality visitor experiences and education. In general, informed visitor management for outdoor recreation is based on a broad strategy supported by specific management actions or tools. In this context, collaborative planning approaches to visitor management are successful in building consensus and management capacity among key stakeholders (see section Governance and participation).

Many guidelines for strategies exist, as well as myriad management tools (Leung et al. 2014). For instance, the Gesäuse National Park (Styria) has developed a visitor management strategy based on the Visitor Experience and Resource Protection framework (VERP, US National Park Service; see Hof \& Lime 1997) and the risk analysis for Natura 2000 species and habitats (Zechner 2007). It considers species' conservation status, the relevance and intensity of recreational activities, and the effectiveness of management actions. Based on a dialogue with recreationists sports associations and fauna experts, the Massif des Bauges Regional Nature Park (French Alps) has developed a scheme for winter recreational activities that facilitates collaboration by using an educational approach.

Table 3 presents an overview of management tools for guiding winter recreation, which can be classified as zoning, infrastructure and soft guidance instruments (Ingold 2005). For instance, the majority of $\mathrm{Al}-$ pine PAs define areas of tranquility or sensitive zones for vulnerable species such as black grouse.

\section{Recommendations}

- Sustainable visitor management entails a multi-step management planning process and includes key stakeholders and outdoor participants in order to come to the best management decisions (Zechner 2007; Leung et al. 2014). Here, a systematic approach to assess impacts, identify areas of conflict and delimit specific management zones with indicators and standards is crucial.

- Attractive information panels and signposts should accompany the delimitation of sensitive zones and be harmonized across areas to facilitate recognition by visitors and recreationists.

- A strong commitment to monitoring is an essential component of a management strategy. Monitoring should be a coordinated effort of partners and stakeholders in order to track current conditions and evaluate the efficacy of management tools. 
Table 3 - Management tools for guiding winter recreation (ALPARC 2016).

\begin{tabular}{|l|l|l|}
\hline Group & Management tool & Examples \\
\hline Zoning & Areas of tranquility for vulnerable species & $\begin{array}{l}\text { Massif des Bauges } \\
\text { Regional Nature Park }\end{array}$ \\
\cline { 2 - 3 } & Priority areas for recreational activities & Les Écrins National Park \\
\hline \multirow{5}{*}{ Infrastructure } & Information panels and signposts (attractive, harmonized design, including cartography) & $\begin{array}{l}\text { German Alpine Club, } \\
\text { Vorarlberg federal state } \\
\text { government }\end{array}$ \\
\cline { 2 - 3 } & $\begin{array}{l}\text { Attractive infrastructure in non-sensitive areas (benches, fauna observation and viewpoints, picnic } \\
\text { areas) }\end{array}$ & Building or closing barriers to reduce access to starting points of routes and areas \\
\hline \multirow{5}{*}{ Soft guidance } & $\begin{array}{l}\text { Provision of maps and attractive information on non-sensitive routes for tour preparation via dif- } \\
\text { ferent analog and digital media }\end{array}$ & $\begin{array}{l}\text { German Alpine Club, } \\
\text { Gesäuse National Park, } \\
\text { Swiss campaign }\end{array}$ \\
\cline { 2 - 3 } & On-site face-to-face information provided by park staff, mountain professionals or volunteers & $\begin{array}{l}\text { Nature reserves Haute- } \\
\text { Savoie }\end{array}$ \\
\cline { 2 - 3 } & Making trails by park staff or volunteers (after snowfall) & Gesäuse National Park \\
\cline { 2 - 3 } & Guidance by habitat management (natural topography, vegetation cover) & \\
\hline
\end{tabular}

- Winter recreationists should respect wildlife and its habitats on a voluntary basis. Strategies and tools of winter recreation management should therefore not be based on prohibition or penalties.

\section{Governance and participation}

The management of winter recreational activities concerns numerous stakeholders from different spheres, at different levels, and with different levels of interest and engagement in the topic. Experience over the last twenty years has shown that management approaches based on good governance principles (e.g. Lockwood 2010) are more successful than those built on directive and regulatory action (Pröbstl \& Prutsch 2010). In a successful initiative, the PA management favours participatory processes that include relevant regional and local stakeholders from the outset (Figure 2). The manager accompanies and steers the development of collectively defined measures and coordinates their implementation with the support of the other stakeholders.

A project design based on early stakeholder participation has multiple advantages. It provides transparency, contributes to increased awareness among stakeholders through information and learning from the beginning, and builds capacity for management (ALPARC 2016). Stakeholder ambassadors can induce changes in attitude and behaviour among other stakeholders. A knock-on effect of a broad-based approach is an increased acceptance of regulatory measures or for jointly defined sensitive zones. Managers judge such an approach more durable since it can change the attitudes and behaviour of relevant stakeholders. Information, awareness-raising and educational tasks, but also the setting up and control of on-site management measures can be adopted and ensured by specific stakeholders, e. g. when funding for an initiative comes to an end (ALPARC 2016).

\section{Recommendations}

- Participatory processes in winter recreation management in PAs need to be carried out on an appropriate scale to be efficient and achieve momentum. It is crucial to include stakeholders beyond the limits of PAs such as national park core zones or nature reserves. Stakeholders of nearby urban centres should also be involved.

- The establishment of good governance requires $a$ clear identification of responsibilities and a manager who initiates, coordinates and steers the group of stakeholders throughout the course of the project (Table 4). The manager needs to be responsive to evolving conflicts and interests. PA managers have both the technical and methodological expertise and the networking capacity to take on this role. The manager should accompany and steer the group of stakeholders according to the group's needs, for the duration of the initiative.

\section{Information and communication}

Initiatives to raise awareness and persuade participants in outdoor recreation to adopt ecologically responsible behaviour have existed in the Alps at different spatial scales for more than 20 years (Table 5). They aim at influencing behaviour and attitudes through information and educational material such as slogans, flyers, on-site information panels, and digital media such as videos and websites. Management and monitoring experiences have shown that in many cases visitors and recreationists' ignorance is at the origin of wildlife disturbance. Research indicates that visitor management and zoning without information material fail to change the behaviour of recreationists (Immoos \& Hunziker 2015). Management approaches thus need information and persuasion tools in order to reduce disturbance effectively. Experts underline that information and awareness levels vary significantly between participants in different activities and geographical areas, but there is also significant intra-group heterogeneity (ALPARC 2016).

Table 5 gives an overview of major information and communication initiatives for winter recreational activities in the Alps, which vary significantly with regard to slogans, graphic identity and scope. Many initiatives are based on the Respektiere Deine Grenzen campaign of the Vorarlberg federal state (Austria). 


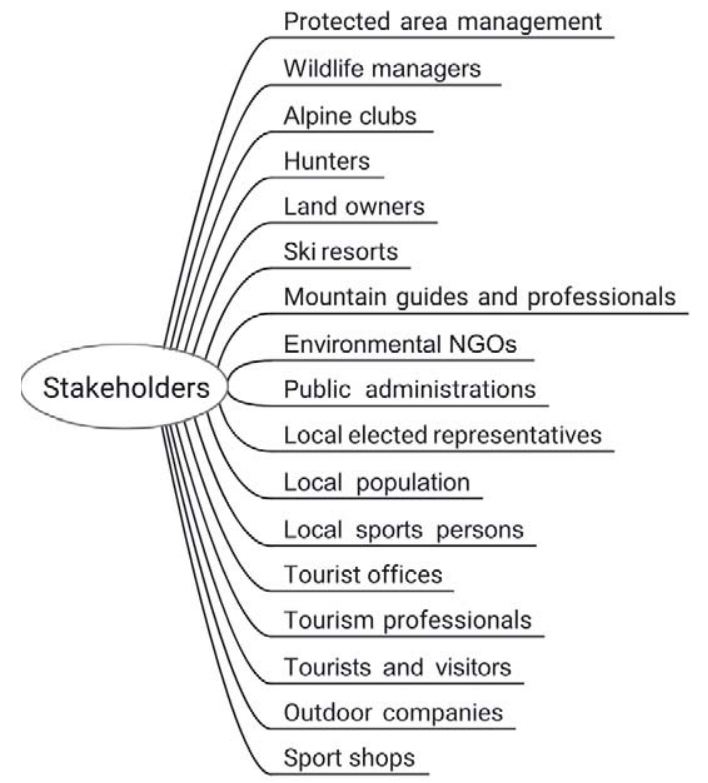

Figure 2 - List of stakeholders for management of winter recreational activities (ALPARC 2016). This list is not exhaustive.

Whereas there are national or regional efforts in Switzerland, the German Alps and Vorarlberg, in many PAs, the initiatives are purely local in scope. All approaches distinguish various target groups.

\section{Recommendations}

- To be effective, an information and communication campaign needs to provide simple, clear, visual and target-oriented messages that address the carefully identified user groups. Given the diversity of user groups, it is advisable to develop various messages using different media and with more or less detailed information. Humour, graphic design and art as well as telling stories about real people (e.g. ambassadors) can be powerful means to convey a message.

- A successful campaign therefore needs sufficient knowledge about user groups, their level of awareness, attitudes and behaviour, and how to influence them. It is therefore advisable to include user groups at the planning and development stages of communication campaigns and information tools.

- Managers should avoid negative and prohibitive messages and prefer positive messages that foster voluntary behavioural changes.

- A successful awareness-raising campaign makes use of various means of communication to reach visitors and recreationists. On-site educational approaches by trained professionals or volunteers are more successful than print or web media, but are also resource intensive.

\section{Evaluation}

Evaluating management measures is critical for the successful management of winter recreational activities. Do information and awareness-raising measures as well as on-site guidance instruments achieve their
Table 4 - Steps in setting up governance of winter recreational activities in protected areas (ALPARC 2016).

\begin{tabular}{|l|}
\hline 1. Identify a coordinator (project initiator) \\
\hline 2. Identify and prioritize stakeholders in the region by inter- \\
est and relevance of the topic. Select key players and local \\
ambassadors. Form a steering committee
\end{tabular}

goal in changing recreationists' behaviour towards an ecologically responsible one? There are very few systematic evaluation studies analysing the effects of these instruments (Immoos \& Hunziker 2015). In Switzerland, qualitative interviews, representative surveys and intervention experiments have been conducted in order to evaluate the nationwide campaign Respektiere Deine Grenzen and its instruments (Zeidnitz et al. 2007; Immoos \& Hunziker 2015). They show that persuasive awareness-raising measures are successful, but that on-site guidance instruments such as prohibition signs and barrier tapes do not add any further impact. Adequate ecological information at starting points of routes influences behaviour positively, whereas guidance instruments without information have no effect (Immoos \& Hunziker 2015). Researchers and managers argue that there seems to be inherent resistance to constraints encountered on a route. Although research shows the success of regulatory measures and fines, these are often costly and difficult to implement. According to evaluation studies, awareness-raising and information measures remain the best choices, since they build on education and acceptance (Immoos \& Hunziker 2015).

\section{Recommendations}

- In general, more research is needed with regard to the evaluation of the effects of communication and guidance instruments. In the context of the Alps, regional cultural differences in motivations for outdoor recreation and perceptions of management measures might reduce the transferability of successful management approaches.

- In order to evaluate the success of management measures, managers should acquire knowledge about the motivations of user groups for outdoor recreation before implementing measures.

- During and after the implementation, managers should use appropriate methods to efficiently monitor behavioural changes of the user groups. Are these changes related to the measures introduced? Managers should use a mix of methods, e. g. surveys and 
Table 5 - Awareness-raising campaigns and communication tools across the Alps. This list is not exhaustive but shows the major campaigns / initiatives presented at the ALPARC workshop in Lescheraines (FR) in 2016 or that are otherwise known to the authors. Various other protected areas contribute to awareness-raising among outdoor recreationists by bighlighting negative impacts on fauna and probibiting access to some areas.

\begin{tabular}{|c|c|c|c|c|c|}
\hline Title & Initiator (country) & Starting year & Area covered & Target groups & Communication toolkit \\
\hline $\begin{array}{l}\text { Respektiere Deine Grenzen } \\
\text { (Respect your Limits) }\end{array}$ & $\begin{array}{l}\text { Vorarlberg federal state } \\
\text { government (AT) }\end{array}$ & 2003 & $\begin{array}{l}\text { Federal state } \\
\text { (Vorarlberg) }\end{array}$ & $\begin{array}{l}\text { Ski tourers, Skiers, free- } \\
\text { riders, snowshoers }\end{array}$ & $\begin{array}{l}\text { Flyers, information panels, } \\
\text { video clips, dedicated } \\
\text { website }\end{array}$ \\
\hline $\begin{array}{l}\text { Respektiere Deine Grenzen } \\
\text { (Respect is to protect) }\end{array}$ & $\begin{array}{l}\text { Campaign funded by FOEN } \\
\text { and CAS }(\mathrm{CH})\end{array}$ & 2009 & Country $(\mathrm{CH})$ & $\begin{array}{l}\text { Ski tourers, Skiers, free- } \\
\text { riders, snowshoers }\end{array}$ & $\begin{array}{l}\text { Flyers, information panels, } \\
\text { video clips, dedicated web- } \\
\text { site, mapping }\end{array}$ \\
\hline $\begin{array}{l}\text { Respecter c'est protéger } \\
\text { (Respect is to Protect) }\end{array}$ & $\begin{array}{l}\text { Massif des Bauges Regional } \\
\text { Nature Park (FR) }\end{array}$ & 2012 & Park perimeter & Ski tourers, snowshoers & $\begin{array}{l}\text { Information panels, dedi- } \\
\text { cated website, information } \\
\text { input to online outdoor plat- } \\
\text { forms, training for mountain } \\
\text { professionals }\end{array}$ \\
\hline $\begin{array}{l}\text { Dein Freiraum. Mein } \\
\text { Lebensraum. (Your space of } \\
\text { freedom, my living space.) }\end{array}$ & $\begin{array}{l}\text { Nagelfluhkette Nature Park, } \\
\text { and regional stakeholders } \\
\text { (DE/AT) }\end{array}$ & 2014 & Park perimeter & Ski tourers, snowshoers & $\begin{array}{l}\text { Flyers, information panels, } \\
\text { information on website }\end{array}$ \\
\hline $\begin{array}{l}\text { Im Winter auf Tour (On tour } \\
\text { in winter) / Überleben im } \\
\text { Winter (Survival in winter) }\end{array}$ & Gesäuse National Park (AT) & 2007 & Park perimeter & Ski tourers & $\begin{array}{l}\text { Information panels, informa- } \\
\text { tion on website, designation } \\
\text { of tour routes }\end{array}$ \\
\hline $\begin{array}{l}\text { Freiheit mit Rücksicht (Free- } \\
\text { dom with respect) }\end{array}$ & $\begin{array}{l}\text { Alpine Club Südtirol, Hunting } \\
\text { and fishing office, and Hunting } \\
\text { association South Tyrol (IT) }\end{array}$ & 2010 & Region (province) & $\begin{array}{l}\text { Ski tourers, Skiers, free- } \\
\text { riders, snowshoers }\end{array}$ & $\begin{array}{l}\text { Flyer, information panels, } \\
\text { information on website }\end{array}$ \\
\hline $\begin{array}{l}\text { Chuuut... / Traces douces } \\
\text { (Shhh - Soft footprints) }\end{array}$ & Les Écrins National Park (FR) & 2009 & Park perimeter & $\begin{array}{l}\text { Outdoor recreationists, } \\
\text { visitors }\end{array}$ & $\begin{array}{l}\text { Flyer, information panels, } \\
\text { information on website }\end{array}$ \\
\hline "Maraudes" hivernales & $\begin{array}{l}\text { Haut-Jura Regional Nature } \\
\text { Park/Association Groupe } \\
\text { Tétras Jura }\end{array}$ & $2014 / 2015$ & $\begin{array}{l}\text { Ski resorts, forest } \\
\text { sites }\end{array}$ & $\begin{array}{l}\text { Outdoor recreationists, } \\
\text { visitors }\end{array}$ & $\begin{array}{l}\text { Video clip, information on } \\
\text { website, on-site information } \\
\text { by educators }\end{array}$ \\
\hline $\begin{array}{l}\text { Skibergsteigen umweltfreund- } \\
\text { lich / Natürlich auf Tour (eco- } \\
\text { friendly ski-touring) }\end{array}$ & German Alpine Club (DE) & 1995 & German Alps & Ski tourers, snowshoers & $\begin{array}{l}\text { Information panels, designa- } \\
\text { tion of tour routes, informa- } \\
\text { tion on website }\end{array}$ \\
\hline
\end{tabular}

interviews with users as well as monitoring of ski tracks after snowfalls.

- The participation of key stakeholders and their ownership of the topic should be monitored and evaluated in the course of the development process.

\section{Conclusion}

This article provides an overview of management approaches to winter recreational activities in the Alps that aim at diminishing wildlife disturbance. Based on the exchanges at the ALPARC workshop Wildlife and winter sport activities, it shows that wildlife disturbance is a relevant topic in nature protection across the Alps, especially within the context of a rising demand for outdoor recreation and a diversification of recreational practices. Numerous initiatives aim to diminish the impacts of recreation regionally and locally. The article presents five essential components that make for successful management practice.

The development of a suitable management strategy should associate key stakeholders at local and regional levels from an early stage in order to guarantee long-term effects. Action and implementation should include both on-site guidance instruments and information and communication measures. Target-oriented information and persuasion remain the best means to raise awareness and change recreationists' behaviour. Although highly effective and appropriate, these measures are costly and not all PA regions use them equally. Given the similarity of the challenges related to winter recreational activities faced by PAs across the whole Alpine region, there is a great potential for the sharing of resources and tools as well as for joint information and communication initiatives in order to reach a greater proportion of recreationists. Finally, managers and campaign initiators should thoroughly evaluate the effects of the management strategy and instruments used on key stakeholders, target groups and wildlife disturbance.

\section{Acknowledgements}

This article is based on exchanges at the workshop Wildlife and winter sport activities coordinated by ALPARC's operational unit, the Massif des Bauges Regional Nature Park, and the Conservatoire d'espaces protégés de Haute Savoie ASTERS. It took place in March 2016 in Lescheraines in the Bauges mountain range and involved 45 stakeholders from six Alpine countries. The authors would like to thank all participants for their commitment to international cooperation in this field and for their active participation in the workshop.

\section{References}

ALPARC (Alpine network of protected areas) 2016. Proceedings of the international Workshop Wildlife and winter sport activities, Lescheraines (France), 3-4 March 2016. Available at: http://wwwalparc. org/news/news-from-the-network-alparc/item/675- 
winter-sports-activities-and-wildlife-is-coexistencepossible-feedback-from-the-international-wildlife-andwinter-sport-activities-workshop (accessed: 29/03/17)

Arlettaz, R., S. Nusslé, M. Baltic, P. Vogel, R. Palme, S. Jenni-Eiermann, P. Patthey \& M. Genoud 2015. Disturbance of wildlife by outdoor winter recreation: allostatic stress response and altered activity - energy budgets. Ecological Application 25: 1197-1212.

Baines, D. \& M. Richardson 2007. An experimental assessment of the potential effects of human disturbance on Black grouse Tetrao tetrix in the North Pennines, England. Ibis 149: 56-64.

Baltic, M., S. Jenni-Eiermann, R. Arlettaz \& R. Palme 2005. A noninvasive technique to evaluate human-generated stress in the Black grouse. Annals of the New York Academy of Sciences 1046: 81-95.

Barja, I., G. Silván, S. Rosellini, A. Piñeiro, A. González-Gil, L. Camacho \& J.C. Illera 2007. Stress physiological responses to tourist pressure in a wild population of European pine marten. Journal of Steroid Biochemistry and Molecular Biology 104: 136-142.

Boonstra, R., D. Hik, G.R. Singleton \& A. Tinnikov 1998. The impact of predator-induced stress on the snowshoe hare cycle. Ecological Monographs 68: 371-394.

Clinchy, M., J. Schulkin, L. Y. Zanette, M.J. Sheriff, P.O. McGowan \& R. Boonstra 2011. The neurological ecology of fear: insights neuroscientists and ecologists have to offer one another. Frontiers in Behavioural Neuroscience, 1-6, Article 21 (Open Access).

Cornelisse, T.M. \& T.P. Duane 2013. Effects of knowledge of an endangered species on recreationists' attitudes and stated behaviours and the significance of management compliance for Ohlone Tiger Beetle conservation. Conservation Biology 27: 1449-1457.

Creel, S., J.E. Fox, A. Hardy, J. Sands, B. Garrott \& R.O. Peterson 2002. Snowmobile activity and glucocorticoid stress responses in wolves and elk. Conservation Biology 16: 809-814.

Formenti, N., R. Viganó, R. Bionda, N. Ferrari, T. Trogu, P. Lanfranchi \& R. Palme 2015. Increased hormonal stress reactions induced in an Alpine Black Grouse (Tetrao tetrix) population by winter sports. Journal of Ornithology 156: 317-321.

Hardiman, N. \& S. Burgin 2010. Adventure recreation in Australia: a case study that investigated the profile of recreational canyoners, their impact attitudes, and response to potential management options. Journal of Ecotourism 9: 36-44.

Herbold, H., F. Suchentrunk \& S. Wagner 1994. Gehegeexperimente zur Wirkung anthropogener Störreize auf Herzfrequenz und Verhalten von Rotund Regwild. Artenschutrreport 4: 51-56. [In German]

Hof, M., \& D.W. Lime 1997. Visitor experience and resource protection framework in the national park system: Rationale, current status, and future direction. In: McCool, S.F. \& D.N. Cole 1997. Proceedings - Limits of Acceptable Change and related planning processes: progress and future directions; 1997 May 20-22; Missoula, MT. Gen. Tech. Rep. INT-GTR-371. U.S. Department of
Agriculture, Forest Service, Rocky Mountain Research Station. Ogden.

Immoos, U. \& M. Hunzinker 2015. The effects of communicative and on-sire measures on the behaviour of winter sports participants within protected mountain areas - results of a field experiment. eco.mont 7: 18-25.

Ingold, P. 2005. Freizeitaktivitäten im Lebensraum der Alpentiere. Bern. [In German]

Jacobs, M., P. Fehres \& M. Campbell 2012. Measuring emotions toward wildlife: a review of generic methods and instruments. Human dimension of wildlife 17(4): 233-247.

Larson, C.L., S.E. Reed, A.M. Merenlender \& K.R. Crooks 2016. Effects of recreation on animals revealed as widespread through a global systematic review. PLOS ONE 11(12): e0167259.

Launer, A.E. \& D.D. Murphy 1994. Umbrella species and the conservation of habitat fragments: A case of a threatened butterfly and a vanishing grassland ecosystem. Biological Conservation 69: 145-153.

Le Corre, N., I. Peuziat, L. Brigand, G. Gélinaud \& C. Meur-Férec 2013. Wintering waterbirds and recreationists in natural areas: a sociological approach to the awareness of bird disturbance. Environmental management 52: 780-791

Leung, Y.F., A. Spenceley, G. Hvenegaard \& R. Buckley 2015. Tourism and visitor management in protected areas. Guidelines for sustainability. Best Practice Protected Area Guidelines Series no. TBA. Gland: IUCN.

Lockwood, M. 2010. Good governance for terrestrial protected areas: A framework, principles and performance outcomes. Journal of Environmental Management 91(3): $\quad 754-766 . \quad$ doi:10.1016/j. jenvman.2009.10.005

Manning, R.E. \& L.E. Anderson 2012. Managing Outdoor Recreation. Case Studies in the National Parks. Oxfordshire \& Cambridge.

Margraf, C., W. Fees \& E. Prechtl 1999. Trendsportarten im Alpenraum. Bund Naturschutz in Bayern e.V. Landesgeschäftsstelle. BN Service GmbH. Regensburg. [In German]

Patthey, P., S. Wirthner, N. Signorell \& R. Arlettaz 2008. Impact of outdoor winter sports on the abundance of a key indicator species of alpine ecosystems. Journal of Applied Ecology 45: 1704-1711.

Perrin-Malterre, C., L. Chanteloup \& L. Gruas 2016. Perceptions and behaviour of winter sports participants in Regional Natural Park of Bauges. VIIe International conference on monitoring and management visitors in recreational and protected areas. University of Novi Sad, 26-30 September 2016.

Pröbstl, U. \& A. Prutsch 2010. Natura 2000 - Outdoor Recreation and Tourism. A guideline for the application of the habitats directive and the birds directive. Federal Agency for Nature Conservation (BfN). Bonn-Bad Godesberg.

Rehnus, M., R. Palme, F. Filli \& K. Hackländer 2010. Seasonal glucocorticoid secretion in mountain hares (Lepus timidus). Mammalia 74: 347-350. 
Rehnus, M., M. Wehrle \& R. Palme 2014. Mountain hares Lepus timidus and tourism activities: Stress events and reactions. Journal of Applied Ecology 51: 6-12.

Reimoser, S. 2012. Influence of anthropogenic disturbance on activity, behaviour and heart rate of roe deer (Capreolus capreaolus) and red deer (Cervus elaphus), in context of their daily and yearly patterns. In: Cahler, A.A. \& J.P. Marsten (eds.), Deer: Habitat, behaviour and conservation. Hauppauge, New York: 1-95.

Sato, C.F., J.T. Wood \& D.B. Lindenmayer 2013. The effects of winter recreation on Alpine and subAlpine Fauna: a systematic review and meta-analysis. PLOS ONE 8(5): e64282.

Sapolsky, R., L.M. Romero \& A.U. Munck 2000. How do glucocorticoids influence stress responses? Integrating permissive, suppressive, stimulatory, and preparative actions. Endocrine Reviews 21: 55-89.

Sheriff, M.J., C.J. Krebs \& R. Boonstra 2009. The sensitive hare: sublethal effects of predator stress on reproduction in snowshoe hares. Journal of Animal Ecology 78: 1249-1258.

Spidsø, T.K., O. Hjeljord, J.D. Dokk 1997. Seasonal mortality of Black grouse Tetrao tetrix during a year with little snow. Wildlife Biology 3: 205-209.

Sterl, P., C. Brandenburg \& A. Arnberger 2008. Visitors' awareness and assessment of recreational disturbance of wildlife in the Donau-Auen National Park. Journal of nature conservation 16: 135-145.

Sterl, P., R. Eder \& A. Arnberger 2010. Exploring factors influencing the attitude of ski tourers towards the ski touring management measures of the Gesäuse National Park. eco.mont 2(1): 31-38.

Taylor, A.R. \& R.L. Knight 2003. Wildlife responses to recreation and associated visitors perceptions. Ecological Applications 13: 951-963.

Thiel, D., S. Jenni-Eiermann, R. Palme \& L. Jenni 2011. Winter tourism increases stress hormone levels in the capercaillie Tetrao urogallus. Ibis 153: 122-133.

Zechner, L. 2007. Visitor management in the Gesäuse National park. A mixed method approach including a checklist. Thesis. Klagenfurt.

Zeidnitz, C., H.J. Mosler \& M. Hunziker 2007. Outdoor recreation: from analysing motivations to furthering ecologically responsible behaviour. Forest snow and landscape research 81: 175-190.

\section{Authors}

\section{Dominik Cremer-Schulte}

is project coordinator for regional development at ALPARC (the Alpine network of protected areas).
He holds a PhD in economics (Grenoble Alpes University) and an engineering degree in spatial planning (TU Dortmund University of Technology). ALPARC - Alpine network of protected areas, 256, rue de la République, F-73000 Chambéry. Email: dominik.cremerschulte@alparc.org

\section{Maik Rehnus}

studied forest sciences and wildlife ecology \& wildlife management at the Institute of Wildlife Biology and Game Management, Vienna. His research focuses on the ecology of the mountain hare in the Alps. He currently works as a member of the scientific staff at Wildtier Schweiz, and is guest scientist at the Swiss Federal Institute for Forest, Snow and Landscape Research WSL, Birmensdorf. Zürcherstrasse 111, CH8903 Birmensdorf.

\section{Antoine Duparc}

studies spatial behaviours of ungulates at the Laboratoire d'Écologie Alpine (French national centre for scientific research) at Savoie Mont Blanc University. His research focuses on the roles of resource availability and human activities in the habitat selection of large herbivores. Laboratoire d'Ecologie Alpine LECA, Université Savoie Mont-Blanc, Campus Scientifique, F-73376 Le Bourget du Lac Cedex.

\section{Clémence Perrin-Malterre}

has been a lecturer at the EDYTEM laboratory of Savoie Mont Blanc University since 2012. Her research in the field of sport sociology focuses on outdoor sports and sport tourism. She studies the environmental management of outdoor sports in protected areas and the diversification of tourist activities in mountain areas. Laboratoire EDYTEM - UMR 5204 du CNRS, Université Savoie Mont-Blanc, Bâtiment Pôle Montagne, F-73376 Le Bourget du Lac Cedex.

\section{Letizia Arneodo}

is project coordinator for mountain-oriented education and communication at ALPARC (the Alpine network of protected areas). She holds a Master's degree in political science (Institute of Political Studies Bordeaux) and works predominantly on the valorization of sustainable education in the Alpine area. ALPARC - Alpine network of protected areas, 256, rue de la République, F-73000 Chambéry. 